\title{
Comment on "Anion Gap Toxicity in Alloxan Induced Type 2 Diabetic Rats Treated with Antidiabetic Noncytotoxic Bioactive Compounds of Ethanolic Extract of Moringa oleifera"
}

\author{
Javad Beheshtipour \\ Young Researchers and Elite Club, Sanandaj Branch, Islamic Azad University, Sanandaj, Iran \\ Correspondence should be addressed to Javad Beheshtipour; j5.beheshtipour@gmail.com \\ Received 27 August 2018; Accepted 21 October 2019; Published 20 November 2019 \\ Academic Editor: Orish Ebere Orisakwe \\ Copyright (C) 2019 Javad Beheshtipour. This is an open access article distributed under the Creative Commons Attribution License, \\ which permits unrestricted use, distribution, and reproduction in any medium, provided the original work is properly cited.
}

I read with interest the article by Omabe et al., entitled "Anion Gap Toxicity in Alloxan Induced Type 2 Diabetic Rats Treated with Antidiabetic Noncytotoxic Bioactive Compounds of Ethanolic Extract of Moringa oleifera," published in this journal (vol. 2014, Article ID 406242) [1]. It is interesting to note that this scientific subject has been dealt with, but one point in the article is the focus of my attention which is discussed below.

Alloxan is one of the oldest chemicals to induce experimental diabetes. It induces type 1 diabetes through a single dose administration in laboratory animals. Alloxan acts in two ways: it selectively inhibits glucose-induced insulin secretion through specific inhibition of glucokinase, the glucose sensor of the beta cell, and it causes a state of insulin-dependent diabetes through its ability to induce reactive oxygen species (ROS) formation, resulting in the selective necrosis of pancreatic beta cells $[2,3]$. Therefore, alloxan cannot induce type 2 diabetes.

In the article by Omabe et al., type 2 diabetes has been induced by a single intraperitoneal injection of alloxan, which is not correct due to its mechanism of action.

\section{Conflicts of Interest}

The author declares that he has no conflicts of interest.

\section{References}

[1] M. Omabe, C. Nwudele, K. N. Omabe, and A. E. Okorocha, "Anion gap toxicity in alloxan induced type 2 diabetic rats treated with antidiabetic noncytotoxic bioactive compounds of ethanolic extract of Moringa Oleifera," Journal of Toxicology, vol. 2014, Article ID 406242, p. 7, 2014.

[2] O. M. Ighodaro, A. M. Adeosun, and O. A. Akinloye, "Alloxaninduced diabetes, a common model for evaluating the glycemiccontrol potential of therapeutic compounds and plants extracts in experimental studies," Medicina, vol. 53, no. 6, pp. 365-374, 2017.

[3] S. Lenzen, "The mechanisms of alloxan- and streptozotocininduced diabetes," Diabetologia, vol. 51, no. 2, pp. 216-226, 2007. 

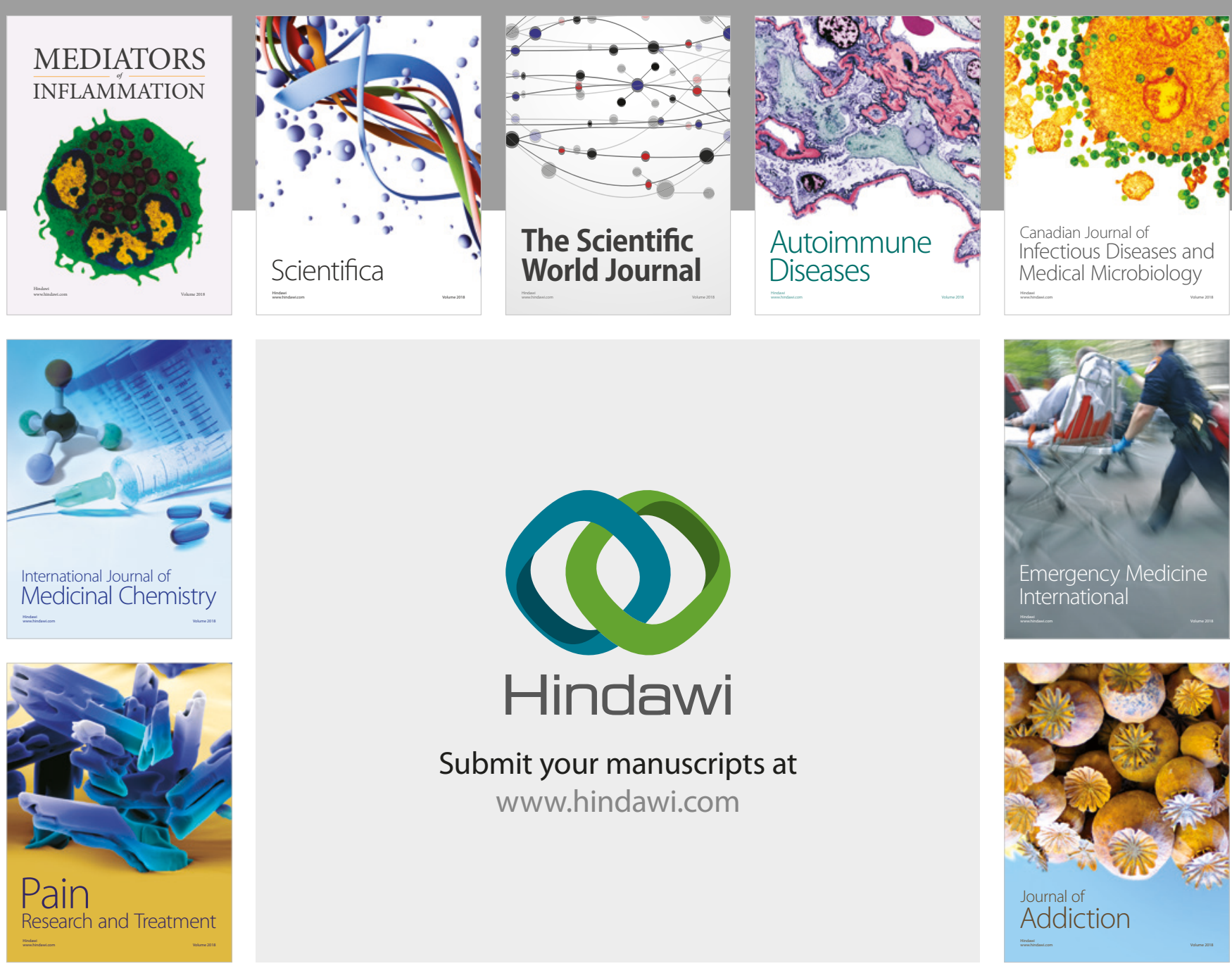

Canadian Journal of
Infectious Diseases and Medical Microbiology

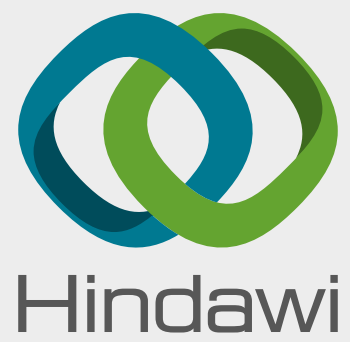

Submit your manuscripts at

www.hindawi.com
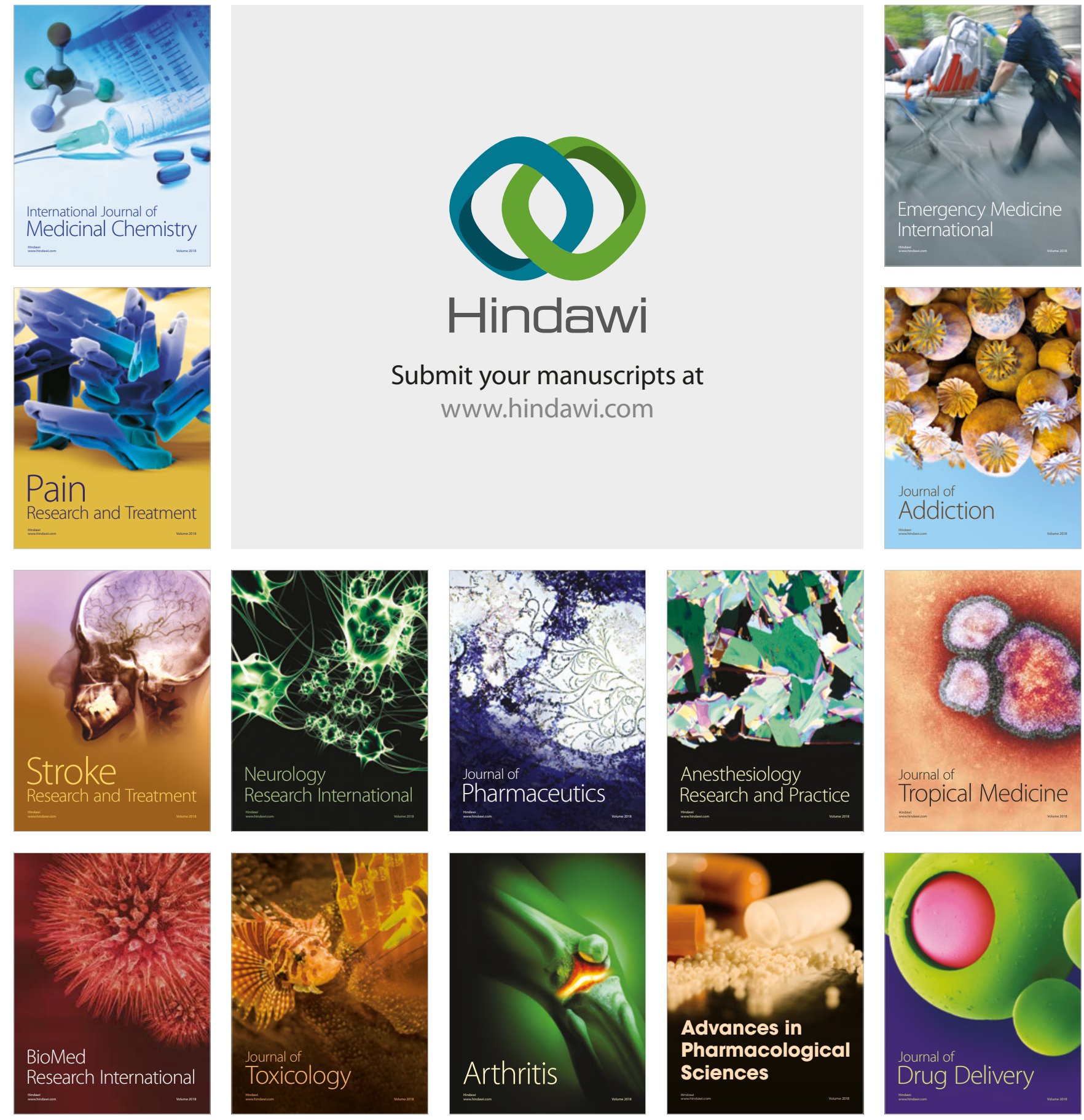